STILES, F. G. 1983a. Birds: introduction. Pp. 502-530 in Janzen, D. H. (ed.). Costa Rican natural history. University Chicago Press, Chicago.

STILES, F. G. 1983b. Checklist of birds. Pp. 530-544 in Janzen, D. H. (ed.). Costa Rican natural history. University Chicago Press, Chicago.

TERBORGH, J. W. 1980. The conservation status of neotropical migrants: present and future. Pp. 21-30 in Keast, A. \& Morton, E. S. (eds). Migrant birds in the neotropics: ecology, behavior, distribution, and conservation. Smithsonian Institution Press, Washington, DC.

WAIDE, R. B., EMLEN, J. T. \& TRAMER, E. J. 1980. Distribution of migrant birds in the Yucatan Peninsula: a survey. Pp. 165-171 in Keast, A. \& Morton, E. S. (eds). Migrant birds in the neotropics: ecology, behavior, distribution, and conservation. Smithsonian Institution Press, Washington, DC.

WETMORE, A., PASQUIER, R. F. \& OLSON, S. L, 1984. The birds of the Republic of Panama, Part 4. Passeriformes: Hirundinidae (Swallows) to Fringillidae (Finches). Smithsonian Miscellaneous Collections, Volume 150, Part 4. Smithsonian Institution Press, Washington, DC. 670 pages.

WILSON, E. O. 1984. Biophilia. Harvard University Press, Cambridge, Mass. 157 pages.

ZAR, J. H. 1974. Biostatistical analysis. Prentice-Hall, Englewood Cliffs, New Jersey. 620 pages.

Accepted 20 January 1987

\title{
ANNOUNCEMENT OF MEETING
}

\section{International Symposium on the Evolutionary Ecology of Tropical Herbivores}

\author{
Univerdade Estadual de Campinas, Campinas, São Paulo, Brazil
}

\section{7-31 March 1988}

Papers by invited speakers will consider Evolutionary Processes in Herbivore Communities, Reciprocal Impact of Herbivores and Plants, Chemical and Nutritional Interactions, Herbivory in Agroecosystems, Mutualisms, Diversity of Herbivores, and the contrast between tropical and temperate ecology. The Symposium will also include poster sessions for contributed reports on the same topics. Conference languages are Portuguese, English and Spanish. For further information please contact:

$\begin{array}{lll}\text { THOMAS M. LEWINSOHN } & \text { or } & \text { G. WILSON FERNANDES } \\ \text { Departmento de Zoologia, IB } & & \text { Department of Biological Sciences } \\ \text { Caixa Postal } 6109 & \text { PO Box } 5640 \\ \text { UNICAMP } & \text { Northern Arizona University } \\ \text { 13081 Campinas, SP } & \text { Flagstaff, AZ 86011 } \\ \text { BRASIL } & \text { USA }\end{array}$

